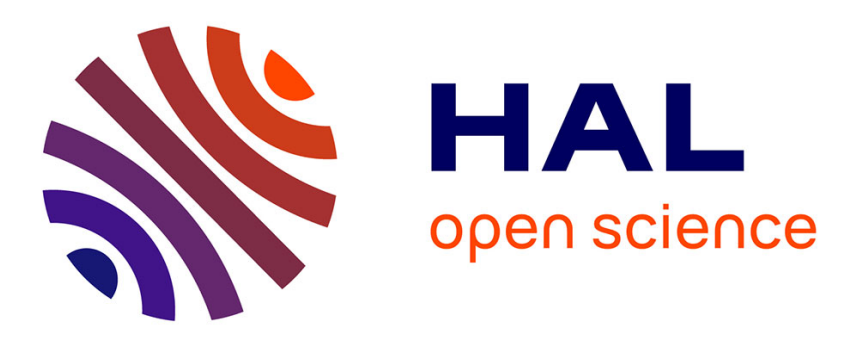

\title{
Improving depth perception during surgical augmented reality
}

Bruno Marques, Nazim Haouchine, Rosalie Plantefeve, Stephane Cotin

\section{To cite this version:}

Bruno Marques, Nazim Haouchine, Rosalie Plantefeve, Stephane Cotin. Improving depth perception during surgical augmented reality. SIGGRAPH [Poster], Aug 2015, Los Angeles, United States. pp.Article No. 24, 10.1145/2787626.2792654 . hal-01191101

\section{HAL Id: hal-01191101 \\ https://hal.inria.fr/hal-01191101}

Submitted on 1 Sep 2015

HAL is a multi-disciplinary open access archive for the deposit and dissemination of scientific research documents, whether they are published or not. The documents may come from teaching and research institutions in France or abroad, or from public or private research centers.
L'archive ouverte pluridisciplinaire HAL, est destinée au dépôt et à la diffusion de documents scientifiques de niveau recherche, publiés ou non, émanant des établissements d'enseignement et de recherche français ou étrangers, des laboratoires publics ou privés. 


\section{Improving Depth Perception during Surgical Augmented Reality}

\author{
Bruno Marques \\ Inria
}

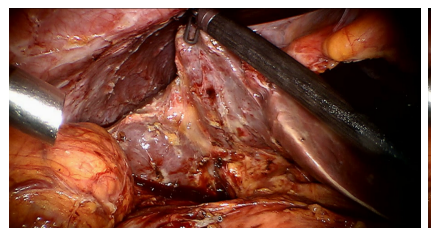

(a)

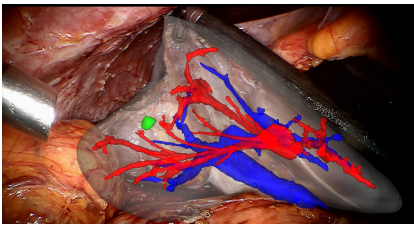

(b)

\author{
Rosalie Plantefeve \\ Altran Medice
}

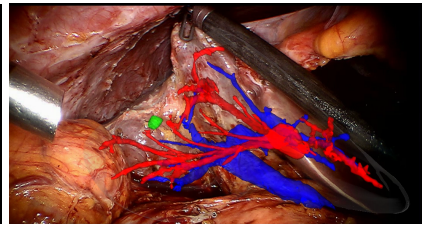

(c)

\author{
Stephane Cotin* \\ Inria
}

Figure 1: Visualization of liver vessels and tumors during Surgical Augmented Reality with (a) the input image, (b) the registration with the original visualization, (c) our method without the adaptive alpha blending and (d) the final output visualization using our method.

\section{Context}

Minimally invasive surgery (MIS) is a recent surgical technique where the surgeon does not interact directly with the patient's organs. In contrast to open surgery, the surgeon manipulates the organs through instruments inserted in the patient's abdominal cavity while observing the organ from a display showing the video stream captured by an endoscopic camera. While the benefits of MIS for patients are clearly claimed, performing these operations remains very challenging for the surgeons, due to the loss of depth perception caused by this indirect manipulation. To tackle this limitation, the research community suggests to use augmented reality (AR) during the procedure [Haouchine et al. 2013]. The objective towards the use of AR during surgery is to be able to overlay the $3 \mathrm{D}$ model of the organ (that can be obtained from a pre-operative scan of the patient) onto the video stream. Surgical AR made considerable advances and reached a certain maturity in the estimation of tumors and vessels localisation. Howerver, very few studies have investigated depth perception and visualization of internal structures [Lerotic et al. 2007], which is considered by surgeons as a very sensitive issue. This study suggests a method to compensate the loss of depth perception while enhancing organ vessels and tumors to surgeons. This method relies on a combination of contour rendering technique and adaptive alpha blending to effectively perceive the vessels and tumors depth. In addition, this technique is designed to achieve real-time to satisfy the requirements of clinical routines, and has been tested on real human surgery.

\section{Technical Approach}

This method relies on the adaptive computation of the alpha blending. To do so, a reference distance is defined, corresponding to the maximum depth perception. This reference distance (denoted $d$ in the following) can be adapted by surgeons during the surgery regarding their needs to perceive depth (surgeon sensitivity to depth perception might vary during the operation). Moreover, the accuracy of the $3 \mathrm{D}$ model registration on the images drops in proportion

*e-mail:stephane.cotin@inria.fr to its depth which makes it highly accountable. Therefore, this parameter should be kept reasonably small to avoid displaying flawed data caused by the limitations of the registration technique. Furthermore, the algorithms is as follows.

Let us denote $V=\left\{v_{i} \in \mathbb{R}^{3}\right\}$ the set of vessels vertices and $S=\left\{s_{i} \in \mathbb{R}^{3}\right\}$ the set of organ surface vertices. The alpha ratio is computed for each vertex of the vessels meshes using a ray-casting technique. At initialization, a ray is projected from the camera optical center $c \in \mathbb{R}^{3}$ to intersect each vertex $v_{i}$ of the vessels. Then, each vertex $s_{i}$ of the organ's surface $s_{i}$ is projected on the previously computed ray to find the closest vertex to the ray following:

$$
\alpha\left[v_{i}\right]=\frac{\left\|v_{i}-p_{i}\right\|}{d}, p_{i}=\underset{s_{j} \in S}{\operatorname{argmin}}\left\|\left(s_{j}-c\right)-\gamma\left(s_{j}-c, v_{i}-c\right)\right\|
$$

where $d$ is the predefined maximal depth distance and $\gamma(a, b)$ is the vector projection of $a$ on $b$.

The organ surface is rendered with a simple contour rendering shader to display the surface of the organ. This will ensure an unobstructed view of the real organ while still allowing the in-depth perception of vessels.

The Figure 1 illustrates the augmented view of a human liver during a laparoscopic liver resection. The visualization takes into account the changing shape of the organ that requires real time computation of the alpha blending step while capturing organ deformations that emanates from instruments manipulation, heart beating and breathing. The maximal depth distance is experimentally set to $d=4 \mathrm{~cm}$. The algorithm performs in near real-time at around $18 \mathrm{fps}$ while using a mesh composed of more than 30.000 vertices, accounting for liver surface, vessels and tumors, thanks to a GPU implementation using NVidia CUDA. Future work will investigate the deployment of this method to the operating room as well as quantify surgeons feedback regarding visualization.

\section{References}

Haouchine, N., Dequidt, J., Peterlik, I., Kerrien, E., BERGER, M.-O., AND COTIN, S. 2013. Image-guided simulation of heterogeneous tissue deformation for augmented reality during hepatic surgery. In ISMAR 2013, 199-208.

Lerotic, M., Chung, A., Mylonas, G., And Yang, G.Z. 2007. pq-space based non-photorealistic rendering for augmented reality. In MICCAI 2007, vol. 4792. 102-109. 